\title{
Analisis Perkembangan Inventasi di Provinsi Papua Barat Tahun 2011-2015
}

\author{
Elina R. Situmorang ${ }^{1}$, Naftali Mansim ${ }^{1}$, Nuur Rohmi Permatasari ${ }^{2}$ \\ ${ }^{1}$ Dosen Fakultas Ekonomi Dan Bisnis, Universitas Papua \\ ${ }^{2}$ Alumni Fakultas Ekonomi Dan Bisnis, Universitas Papua \\ Permalink/DOI: http://dx.doi.org/10.32830/jfres.v1i1.1027.g775
}

Received: May 2018; Accepted: July 2018; Published: September 2018

\begin{abstract}
Abstrak
Tujuan penelitian ini adalah untuk mengetahui perkembangan investasi dan untuk mengetahui sektor potensial dalam perkembangan investasi yang terjadi di Papua Barat periode tahun 2011-2015. Jenis data yang digunakan dalam penelitian ini adalah data sekunder yang diperoleh dari Badan Penanaman Modal Dan Pelayanan Perizinan Terpadu (BPMP2T) Provinsi Papua Barat. Metode analisis data yang digunakan adalah deskriptif tabulasi. Hasil analisis menunjukkkan bahwa perkembangan realisasi investasi PMDN di Papua Barat mengalami peningkatan dari tahun 2011 hingga 2015. Hal ini disebabkan oleh semakin membaiknya administrasi perijinan mengenai penanaman modal di provinsi ini. Sementara itu, perkembangan realisasi investasi PMA di Papua Barat mengalami fluktuasi namun cenderung mengalami penurunan. Hasil analsis juga mengindikasikan bahwa penetapan sektor potensial PMDN tertinggi adalah Kabupaten Sorong, dengan bidang usaha perkebunan kelapa sawit, sedangkan penetapan sektor potensial untuk PMA adalah Kabupaten Raja Ampat, dengan bidang usaha pertambangan umum.
\end{abstract}

Kata kunci: perkembangan investasi, PMDN, PMA

\begin{abstract}
This research aims to describe the investment growth in Papua Barat between 2011 and 2015, and to analyse the potential sectors related to the growth of investment. Data used in this research was secondary data sourced from Badan Penanaman Modal dan Pelayanan Perizinan Terpadu (BPMP2T) of Papua Barat. Data was then analysed using descriptive tabulation method. The results indicated that the realisation of domestic investment in Papua Barat increased from 2011 to 2015. This is because the administrative processes in terms of investment licensing were getting better in this province. The results also highlighted that the realization of foreign investment in Papua Barat was fluctuative, and even more likely to decrease during the similar period. In addition, the findings also indicated that the potential sector that had the highest domestic investment was palm oil plantation sector in Sorong regency, and the potential sector that had the highest foreign investment was general mining sector in Raja Ampat regency.
\end{abstract}

Keywords: investment growth, domestic investment, foreign investment

How to Cite: Situmorang, E.R., Mansim, N., Permatasari, N.R. (2018). Analisis Perkembangan Inventasi di Provinsi Papua Barat Tahun 2011-2015. JFRES: Journal of Fiscal and Regional Economy Studies, 1 (1), 77-94. doi: http://dx.doi.org/10.32830/jfres.v1i1.1027.g775 


\section{PENDAHULUAN}

Pembangunan merupakan suatu proses multidimensional yang mencakup berbagai perubahan mendasar atas struktur sosial, sikap-sikap masyarakat dan institusi-institusi nasional, disamping tetap mengejar akselerasi pertumbuhan ekonomi, penanganan ketimpangan pendapatan, serta pengentasan kemiskinan (Todaro, 2006). Oleh karena itu, pada hakekatnya, pembangunan itu harus mencerminkan perubahan total suatu masyarakat atau penyesuaian sistem sosial secara keseluruhan, tanpa mengabaikan keragaman kebutuhan dasar dan keinginan individual maupun kelompok-kelompok sosial yang ada di dalamnya, untuk bergerak maju menuju suatu kondisi kehidupan yang serba lebih baik secara material maupun spiritual.

Pembangunan ekonomi daerah adalah suatu proses dimana pemerintah daerah dan masyarakatnya mengelola sumber daya yang ada dan membentuk suatu pola kemitraan antara pemerintah daerah dengan sektor swasta untuk menciptakan suatu lapangan kerja baru dan merangsang perkembangan pertumbuhan ekonomi dalam wilayah tersebut (Arsyad, 1999). Setiap upaya pembangunan ekonomi daerah mempunyai tujuan utama untuk meningkatkan jumlah dan jenis peluang kerja untuk masyarakat daerah. Dalam upaya untuk mencapai tujuan tersebut, pemerintah daerah dan masyarakatnya harus secara bersama-sama mengambil inisiatif dalam pembangunan daerah. Oleh karena itu, pemerintah daerah beserta partisipasi masyarakatnya dan dengan menggunakan sumber daya - sumber daya yang ada harus mampu menaksir potensi sumber daya yang diperlukan untuk merancang dan membangun perekonomian daerah (Arsyad, 2004). Untuk mendukung upaya pembangunan ekonomi daerah, pemerintah daerah perlu membuat kebijakan yang mendukung penanaman modal yang saling menguntungkan baik bagi pemerintah daerah, pihak swasta maupun terhadap masyarakat. Tumbuhnya iklim investasi yang sehat dan kompetitif diharapkan akan memacu perkembangan investasi yang saling menguntungkan dalam pembangunan daerah.

Trisno (2003) melakukan penelitian mengenai analisis faktor-faktor yang berpengaruh terhadap penanaman modal asing (PMA) dan penanaman modal dalam negeri (PMDN) di Provinsi Jawa Tengah Tahun 1970 - 2000. Hasil penelitiannya adalah faktor ketersediaan jalan beraspal mempunyai pengaruh terbesar dan positif terhadap PMA dan PMDN. Begitu pula dengan PDRB yang mempunyai pengaruh positif terhadap PMA dan PMDN, sedangkan suku bunga internasional mempunyai pengarh negatif terhadap PMA, dan suku bunga kredit pun berpengaruh negatif terhadap PMDN. Putra (2010), melihat pengaruh suku bunga kredit, PDB, inflasi dan tingkat teknologi terhadap PMDN di Indonesia periode 1986 - 2008. Hasil penelitian ini menunjukkan bahwa tingkat suku bunga kredit berpengaruh positif terhadap PMDN di Indonesia. Hal ini dikarenakan tingkat inflasi lebih tinggi dibandingkan dengan kenaikan tingkat suku bunga. PDB berpengaruh secara positif dan signifikan terhadap PMDN di Indonesia pada periode 1986 - 2008.

Menurut Samuelson (1996), investasi atau penanaman modal adalah pembelian barangbarang modal yang meliputi penambahan stok modal atau barang modal disuatu negara, seperti pembangunan, peralatan produksi dan barangbarang inventori dalam waktu satu tahun. Investasi merupakan tambahan stok barang tahan lamayang akan memperbesar peluang produksi dimasa yang akan datang. Investasi atau stok modal merupakan salah satu faktor penting dalam menentukan pertumbuhan ekonomi dan pembangunan ekonomi.

Provinsi Papua Barat memiliki beragam kekayaan sumber daya alam namun belum terkelola dengan baik, karena itu investasi dan penanaman modal menjadi salah satu hal penting untuk menopang dan mempercepat pembangunan. Sebagai provinsi baru, Papua Barat memiliki keterbatasan dana untuk mencakupi upaya pembangunan ekonominya. Melihat kondisi tersebut, maka peningkatan modal sangat berperan penting untuk meningkatkan perekonomian. Oleh karena itu pemerintah dan swasta berupaya meningkatkan pertumbuhan ekonomi melalui penghimpunan dana yang diarahkan pada kegiatan ekonomi produktif yaitu dengan menggenjot investasi swasta, baik berupa PMDN maupun PMA. Perkembangan nilai investasi swasta yang telah terealisasi dan mendapatkan persetujuan pemerintah secara kumulatif Provinsi Papua 
Barat, termasuk proyek baru, disajikan pada Tabel 1.

Berdasarkan uraian diatas, maka pertanyaan penelitian ini adalah sejauh mana perkembangan investasi di Papua Barat. Sehingga tujuan penelitian ini adalah 1) mengetahui perkembangan investasi di Provinsi Papua Barat tahun 2011 sampai 2015, dan 2) menganalisis sektor potensial dari perkembangan investasi yang terjadi di Papua Barat tahun 2011 sampai 2015.

\section{METODE PENELITIAN}

Penelitian ini merupakan penelitian deskriptif kuantitatif, sumber data sekunder diperoleh dari Badan Penanaman Modal Dan Pelayanan Perizinan Terpadu (BPMP2T) Provinsi Papua Barat. Perkembangan investasi diukur dengan cara aritmatika yaitu selisih antara nilai investasi (PMDN) yang ingin diketahui dengan investasi (PMDN) pada tahun sebelumnya, dan dibagi investasi (PMDN) pada tahun sebelumnya kemudian dikalikan dengan 100\%.

$$
\text { P. } \mathrm{I}_{(\mathrm{PMDN})}=\frac{\mathrm{I}_{(\mathrm{PMDN}) \mathrm{t}}-\mathrm{I}_{(\mathrm{PMDN}) \mathrm{t}-1}}{\mathrm{I}_{(\mathrm{PMDN}) \mathrm{t}-1}} \times 100 \%
$$

Perkembangan investasi ini tidak hanya dianalisis pada perkembangan total, tetapi juga dilakukan perkembangan berdasarkan kabupaten/kota, sektor usaha dan serapan tenaga kerja dengan cara yang sama. Sementara itu, sektor potensial dapat diukur dengan menilai sektor penanam investasi terbesar baik dalam sektor usaha maupun serapan tenaga kerja. Metode analisis data yang digunakan dalam penelitian ini adalah deskriptif tabulasi.

\section{HASIL DAN PEMBAHASAN}

\section{Kondisi PDRB Papua Barat Tahun 2014}

PDRB merupakan nilai tambah yang dihasilkan

Tabel 1. Nilai Investasi dan Jumlah Proyek PMDN dan PMA di Provinsi Papua Barat Tahun 2011-2015

\begin{tabular}{cccccc}
\hline \multirow{2}{*}{ No } & \multirow{2}{*}{ Tahun } & \multicolumn{2}{c}{ PMDM } & \multicolumn{2}{c}{ PMA } \\
\cline { 3 - 6 } & & Jumlah Proyek & Nilai Investasi (Rp.) & Jumlah Proyek & Nilai Investasi (Rp.) \\
\hline 1 & 2011 & 19 & 948.925 .000 .000 & 20 & 617.355 .000 .000 \\
2 & 2012 & 21 & 683.196 .000 .000 & 31 & 586.818 .000 .000 \\
3 & 2013 & 3 & 16.410 .585 .589 & 38 & 3.915 .768 .252 .890 \\
4 & 2014 & 3 & 468.561 .635 .873 & 35 & 3.164 .815 .500 .000 \\
5 & 2015 & 5 & 80.630 .482 .651 & 42 & 3.622 .087 .500 .000 \\
\hline
\end{tabular}

Sumber: BPMP2T Papua Barat oleh seluruh nilai barang dan jasa yang dihasilkan seluruh unit usaha ekonomi suatu wilayah dalam satu tahun. Unit-unit ekonomi tersebut mencakup sektor pertanian, sektor pertambangan, sektor industri pengolahan, sektor pengadaan listrik, dan air bersih, sektor kontruksi, sektor perdagangan, sektor transportasi, sektor penyediaan akomodasi, sektor informasi dan komunikasi, sektor real estate, dan sektor jasa-jasa. Berikut merupakan gambaran unit usaha dalam PDRB Papua Barat tahun 2014.

Gambar 1 menunjukkan bahwa dalam PDRB tahun 2014, sektor industri pengolahan memiliki kontribusi terbesar dibandingkan enam belas sektor lainnya yaitu sebesar 32\%. Kontribusi terbesar kedua disumbangkan oleh sektor pertambangan sebesar 22\%. Sedangkan sektor yang mempunyai kontribusi terendah dalam PDRB diantaranya adalah sektor Pengadaan listrik, sektor pengadaan air bersih, sektor penyediaan akomodasi dan makan minum, sektor jasa perusahaan dan jasa lainnya yaitu sebesar $0 \%$.

\section{Perkembangan Investasi PMDN di Provinsi Papua Barat}

Perkembangan investasi PMDN di Provinsi Papua Barat di analisis selama lima tahun terakhir yaitu tahun 2011-2015. Pada tahun 2011-2013 dilakukan analisis pada 10 kabupaten dan 1 kota sedangkan pada tahun 2014-2015 dilakukan analisis di 12 kabupaten dan 1 kota. Perkembangan investasi PMDN dianalisis baik rencana maupun realisasi investasi yang terjadi di Provinsi Papua Barat. Perkembangan realisasi PMDN tersebut dapat dilihat pada Gambar 2. 


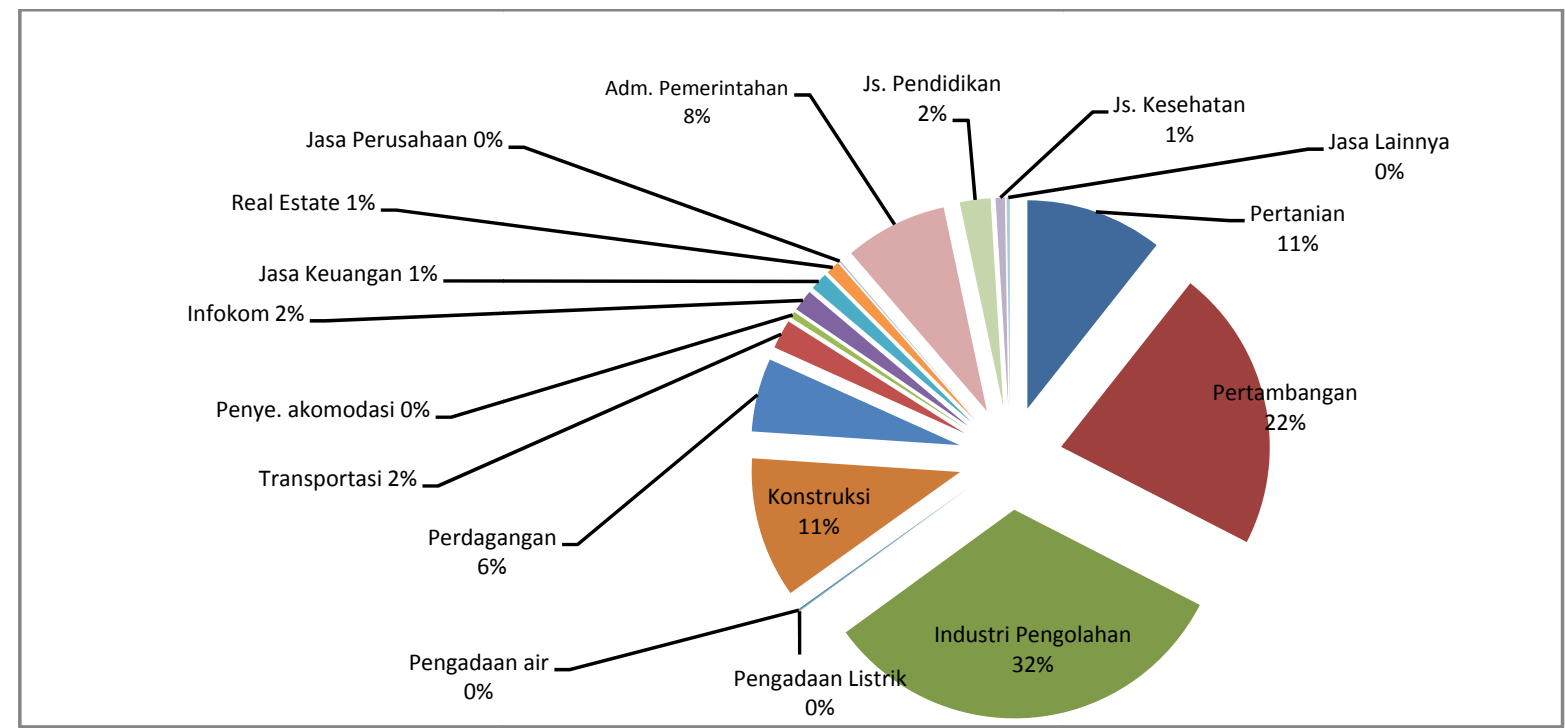

Sumber: BPS Papua Bara (diolah), 2015

Gambar 1. Kondisi PDRB Papua Barat Tahun 2014

Berdasarkan grafik pada Gambar 2, rencana investasi PMDN di Provinsi Papua Barat cenderung mengalami penurunan. Berbeda dengan realisasi investasi PMDN terus mengalami peningkatan hingga tahun 2014. Tabel diatas juga menggambarkan bahwa realisasi atas rencana investasi yang dilakukan mengalami fluktuatif. Realisasi atas rencana investasi hanya sebesar 20\% Tahun 2011 dan 25,59\% pada Tahun 2012, namun terjadi peningkatan realisasi pada Tahun 2013 menjadi sebesar 211\% dan pada Tahun 2014 sebesar 495\%. Peningkatan ini terjadi karena semakin banyak jumlah perusahaan PMDN yang berinvestasi di Papua Barat melalui administrasi perijinan yang dikeluarkan. Fluktuasi perkembangan investasi perusahaan dalam negeri seperti diatas menurut Suryana (2000) dapat disebabkan; Pertama, kecilnya jumlah mutlak kapita material. Kedua, terbatasnya kapasitas dan keahlian penduduk. Ketiga dan yang terakhir adalah rendahnya investasi netto. Akibat keterbatasan tersebut terlihat bahwa Papua Barat masih memiliki sumber daya yang belum dikembangkan dan sumber daya manusia yang masih potensial.

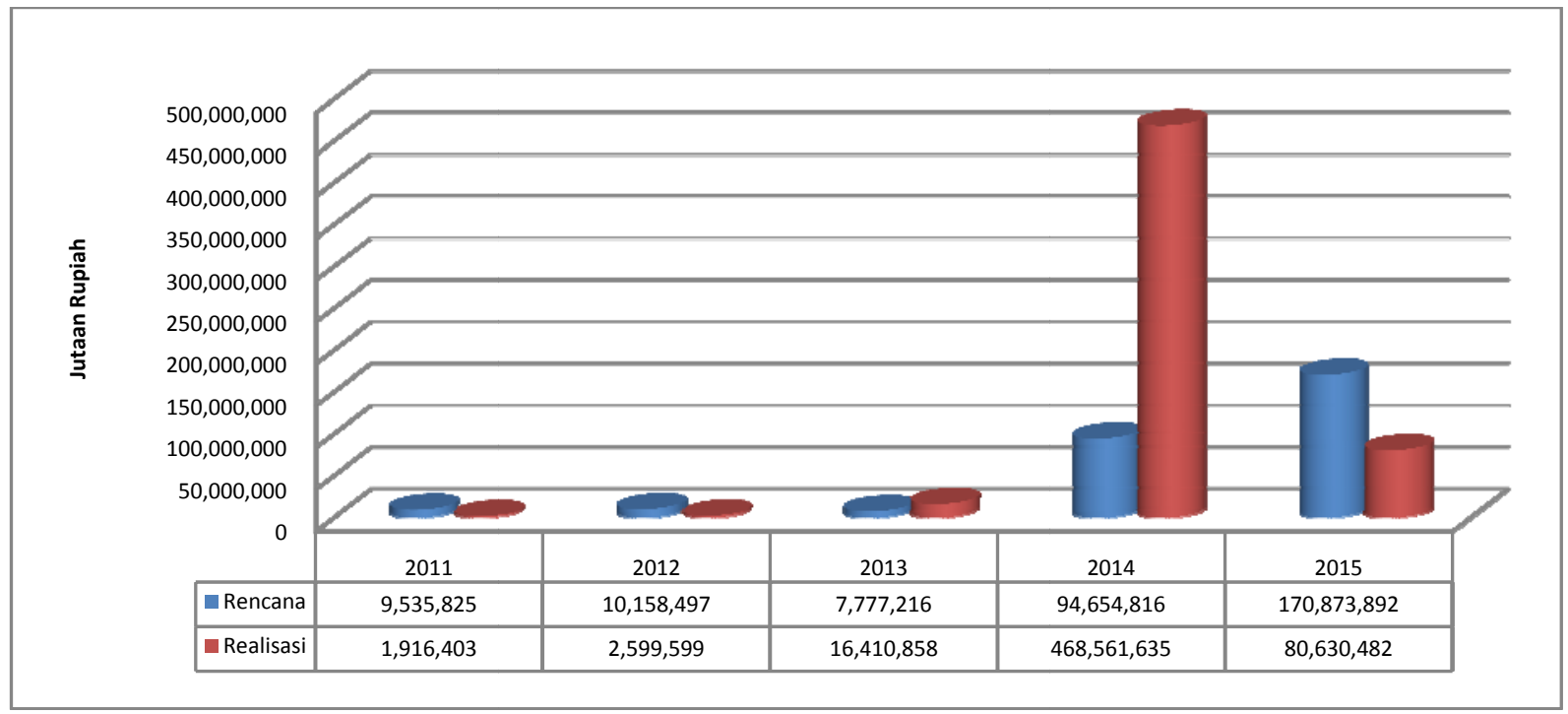

Sumber: Data sekunder (diolah), 2016

Gambar 2. Rencana dan realisasi PMDN Provinsi Papua Barat 2011-2015 


\section{Perkembangan PMDN Berdasarkan Kabupaten/ Kota}

Perkembangan PMDN berdasarkan kabupaten ini akan dilakukan di seluruh kabupaten dan kota yang ada di Papua Barat. Perkembangan ini dilakukan dengan menganalisis perkembangan realisasi PMDN pada setiap kabupaten/kota sejak tahun 2011 hingga tahun 2015. Uraian mengenai perkembangan PMDN berdasarkan kabupaten/kota dapat dilihat pada Tabel 2.

Realisasi PMDN di kabupaten Manokwari di tahun 2013 pengalami penurunan drastis menjadi 1,96\%. Penurunan ini terjadi di disebabkan pada tahun 2013 banyak PMDN beralih menjadi PMA. Pada tahun 2014 terjadi lagi peningkatan yang cukup besar yaitu sebesar 548,18\%, hal ini disebabkan banyak PMDN yang masuk dan berinvestasi di Kabupaten Manokwari. Kemudian mengalami penurunan pada tahun 2015 hanya menjadi 57,57\%. Hal ini dapat disimpulkan bahwa di Kabupaten Manokwari realisasi investasi oleh PMDN mengalami fluktuatif.

Hal yang berbeda tejadi di Kabupaten Sorong, terjadi peningkatan investasi PMDN yaitu dari tahun 2011 hanya sebesar 7,92\% hingga tahun 2014 menjadi 1.924,01\%. Walaupun terjadi penurunan di tahun 2015 menjadi sebesar
436,69\%. Untuk realisasi PMDN pada kabupaten Kaimana, Kabupaten Teluk Bintuni dan kabupaten Raja Ampat pada tahun 2011-2012 adalah konstan. Kemudian tahun 2013-2014 realisasi PMDN ketiga kabupaten tersebut mempunyai realisasi PMDN 0\%.

Terdapat juga daerah yang awalnya yaitu tahun 2011-2012 mengalami pertumbuhan investasi, namun 3 (tiga) tahun terakhir mengalami pertumbuhan realisasi investasi sebesar $0 \%$. Keadaan ini terjadi di Kabupaten Fakfak dan Kota Sorong. Hal ini diduga karena Kabupaten Fakfak memiliki aksesibilitas relatif rendah, sementara itu kota sorong tidak terkovernya jumlah investasi yang ada. Pada kenyataannya didaerah ini tumbuh subur Usaha Kecil Mikro Menengah dan Koperasi (UMKMK) salah satu investor pada PMDN yang seharusnya terjadi peningkatan realisasi dari tahun ke tahun.

Pada Kabupaten Maybrat, terjadi realisasi PMDN di tahun 2015 sebesar 952,85\%. Hal ini disebabkan Kabupaten Maybrat merupakan kabupaten pemekaran dengan pertumbuhan realisasi investasi PMDN relatif besar. Investasi tersebut terfokus pada sektor tanaman pangan dan perkebunan dibidang perkebunan kelapa sawit, hal ini sesuai dengan kondisi lahan yang ada di daerah tersebut.

Tabel 2. Realisasi PMDN Berdasarkan Kabupaten/Kota (\%)

\begin{tabular}{|c|c|c|c|c|c|c|}
\hline \multirow{2}{*}{ No. } & \multirow{2}{*}{ Kabupaten/Kota } & \multicolumn{5}{|c|}{ Tahun } \\
\hline & & 2011 & 2012 & 2013 & 2014 & 2015 \\
\hline 1 & Manokwari & 43,19 & 53,07 & 1,96 & 548,18 & 57,57 \\
\hline 2 & Kaimana & 56,61 & 56,61 & 0 & 0 & 0 \\
\hline 3 & Fakfak & 60,48 & 61,27 & 0 & 0 & 0 \\
\hline 4 & Sorong & 7,92 & 13,88 & 347,99 & 1924,01 & 436,69 \\
\hline 5 & Kota Sorong & 16,99 & 40,65 & 0 & 0 & 0 \\
\hline 6 & Teluk Bintuni & 661,36 & 661,36 & 0 & 0 & 0 \\
\hline 7 & Teluk Wondama & & & & & \\
\hline 8 & Raja Ampat & 112,33 & 112,33 & 0 & 0 & 0 \\
\hline 9 & Sorong Selatan & & & & & \\
\hline 10 & Maybrat & & & & 0 & 952,85 \\
\hline 11 & Tambraw & & & & & \\
\hline 12 & Manokwari Selatan & & & & 0 & 0 \\
\hline 13 & Pegunungan Arfak & & & & & \\
\hline
\end{tabular}

Sumber: Data sekunder (diolah), 2016 
Terdapat juga daerah-daerah yang belum terlihat perkembangan realisasi PMDN. Daerah-daerah tersebut adalah Kabupaten Teluk Wondama, Kabupaten Sorong Selatan, kabupaten Tambraw, kabupaten Manokwari selatan dan Kabupaten Pegunungan Arfak. Hal ini diduga terdapat beberapa faktor penyebab diantaranya adalah (1) Kabupaten-kabupaten tersebut jauh dari pusat provinsi, (2) Aksesibilitas daerah cukup rendah, dan (3) Kurangnya promosi investasi oleh daerah. Daerah yang jauh dari pusat provinsi menyebabkan banyak investor belum melirik daerah tersebut. Aksesibilitas sangat menunjang dalam merangsang investasi, aksesibilitas ini tidak hanyaberupa tersedianya sarana dan prasaran daerah, juga aksesibilitas keamanan investasi yang belut terlihat oleh insvestor untuk menanamkan investasinya. Aspek promosi peluang usaha sangat dibutuhkan oleh investor untuk meyakinkan usaha-usaha yang akan dikelola oleh investor atas modal yang ditanamnya.

\section{Perkembangan PMDN Berdasarkan Sektor Usaha}

Perkembangan PMDN berdasarkan sektor usaha akan dilakukan pada setiap sektor usaha pada setiap kabupaten/ kota yang ada di provinsi Papua Barat. Sektor usaha usaha tersebut diantaranya adalah sektor tanaman pangan dan perkebunan, sektor perikanan, sektor kehutanan, sektor pertambangan, sektor industri kayu, sektor industri kimia, sektor industri lainnya, sektor perdagangan dan reparasi, sektor hotel dan restoran dan sektor jasa lainnya. Uraian mengenai perkembangan PMDN berdasarkan sektor usaha dapat sebagai berikut.

Investasi PMDN Kabupaten Manokwari tahun 2011-2015 sebagian besar terjadi pada sektor usaha tanaman pangan dan perkebunan dan bergerak pada bidang usaha perkebunan kelapa sawit (Tabel 3). Hal ini diduga karena dengan berinvestasi di bidang kelapa sawit, investor dapat meraih keuntungan tinggi mengingat bahwa kondisi tanah di Kabupaten Manokwari sangat potensial. Sektor usaha yang berkontribusi pada PMDN Kabupaten Manokwari selanjutnya adalah sektor usaha perikanan yeng bergerak pada bidang usaha pembekuan ikan. Pertumbuhan realisasi invetasi hanya terjadi di tahun 2011 dan 2012 dengan persentase realisasi yang stagnan yaitu sebesar 66,52\%.Pada tahun 2013 hingga 2015 tidak lagi terjadi realisasi PMDN. Hal ini disebabkan adanya moratorium perijinan penangkapan ikan yang dikeluarkan oleh Kementrian Kelautan dan Perikanan RI yang dapat menghambat operasional perusahaan.

Investasi PMDN di Kabupaten Sorong terlihat tidak jauh berbeda dengan Kabupaten Manokwari, dimana investasi yang terjadi terbatas pada sektor pertanian tanaman pangan dan perkebunan seperti pada Tabel 4.

Sektor usaha yang berkontribusi dalam PMDN Kabupaten Sorong adalah sektor usaha tanaman pangan dan perkebunan yang bergerak dibidang usaha perkebunan kelapa sawit pada tahun 2011 dan 2012 adalah 0\%, hal ini terjadi karena banyak perusahaan PMDN yang tidak disiplin dalam menyampaikan Laporan Kegiatan Penanaman Modal (LKPM), selanjutnya pada tahun 2013 adalah sebesar 545,57\%. Tahun 2014 realisasi sektor ini meningkat drastris menjadi 3.152,49\%, dan kemudian mengalami penurunan menjadi $412.03 \%$.

Sektor usaha kehutanan yang bergerak pada bidang usaha logging pada tahun 2011 adalah sebesar 14,21 selanjutnya menurun menjadi

Tabel 3. PMDN Kabupaten Manokwari Tahun 2011-2015 (\%)

\begin{tabular}{lccccc}
\hline \multicolumn{1}{c}{ Sektor Usaha } & $\mathbf{2 0 1 1}$ & $\mathbf{2 0 1 2}$ & $\mathbf{2 0 1 3}$ & $\mathbf{2 0 1 4}$ & $\mathbf{2 0 1 5}$ \\
\hline Tanaman pangan dan perkebunan & 27,07 & 41,32 & 4,72 & 556,66 & 57,63 \\
Kehutanan & - & 0 & 0 & 0 & - \\
Perikanan & 66,52 & 66,52 & 0 & 0 & - \\
Industri kayu & 0 & 0 & 0 & 0 & 0 \\
Industri lainnya & 0 & 0 & 0 & 0 & - \\
\hline
\end{tabular}

Sumber: Data sekunder (diolah), 2016 
Tabel 4. PMDN Kabupaten Sorong tahun 2011-2015 (\%)

\begin{tabular}{lccccc}
\hline \multicolumn{1}{c}{ Sektor Usaha } & $\mathbf{2 0 1 1}$ & $\mathbf{2 0 1 2}$ & $\mathbf{2 0 1 3}$ & $\mathbf{2 0 1 4}$ & $\mathbf{2 0 1 5}$ \\
\hline Tanaman pangan dan perkebunan & 0 & 0 & 545,57 & $3.152,49$ & 412,03 \\
Kehutanan & 14,21 & 11,27 & 0 & 0 & 0 \\
Perikanan & 0 & $2.777,78$ & 0 & 0 & 0 \\
Pertambangan & 0 & 0 & 0 & 0 & 0 \\
Industri kimia & 0,07 & 23,43 & 66,15 & 0 & 0 \\
Industri kayu & $5.243,58$ & 36,90 & $-*$ & $-*$ & 8,6 \\
Industri lainna & 980,12 & 0 & 0 & 0 & 0 \\
\hline
\end{tabular}

*Tidak ada target dan realisasi

Sumber: Data sekunder (diolah), 2016

11,27\% di tahun 2012, dan kemudian menjadi 0\% pada 3(tiga) tahun terakhir. Hal ini diduga semakin baiknya pengawasan terhadap kehutanan terutama pelarangan logging. Realisasi sektor usaha perikanan di bidang usaha industri pengalengan ikan hanya terjadi pada tahun 2012 yaitu sebesar 2.777,78.

Selanjutnya realisasi sektor usaha pertambangan di bidang usaha pertambangan pasir pada tahun 2011-2015 adalah sebesar 0\%, pada sektor usaha ini tidak memiliki realisasi namun terdapat perencanaan sebesar 10.050 ribu rupiah tiap tahunnya, hal ini diduga karena perusahaan yang bergerak pada bidang usaha ini sudah terdaftar pada badan penanaman modal namun meraka tidak melaporkan realisasi PMDN yang mereka miliki. Realisasi sektor usaha industri kimia dibidang industri kimia dasar organik farmasi mengalami peningkatan dari tahun 2011, 2012 dan 2013, masing-masing nilai realisasinya adalah sebesar $0,07 \%, 23,43 \%$ dan $66,15 \%$. Namun pada tahun 2014-2015 realisasi sektor usaha ini menjadi $0 \%$.

Pertumbuhan realisasi sektor usaha industri kayu dibidang usaha industri kayu dan plywood blockboard pada tahun 2011 adalah sebesar 5.243,58\%, namun pada tahun 2012 menurun menjadi 36,90\%, hal ini terjadi karena perencanan terhadap sektor usaha ini meningkat dari tahun 2011 ke tahun 2012 sehingga persentase capaian realisasinya menurun. Kemudian, tahun tahun 2013-2015 tidak terdapat perencanaan terhadap sektor usaha ini sehingga tahun 2013 dan 2014, capaian realisasinya adalah 0\%, hal ini tidak terjadi pada tahun 2015 karena walaupun tidak ada rencana investasi namun terdapat realisasi investasi sebesar Rp. 8.618.000.000. Pertumbuhan capaian realisasi sektor usaha industri lainnya yang bergerak di bidang usaha pembangkit tenaga listrik dan industri hanya terdapat pada tahun 2011, yaitu sebesar $980,12 \%$.

Realiasasi investasi PMDN Kabupaten Kaimana disumbangkan oleh sektor usaha tanaman pangan dan perkebunan yang bergerak pada bidang usaha perkebunan kelapa dan coklat yaitu sebesar 85,05\%. Sektor usaha kehutanan bergerak pada bidang usaha logging sebesar16,96\% dan sektor usaha perikanan bergerak pada bidang usaha industri pembekuan ikan sebesar $66,01 \%$. Nilai realisasi ketiga sektor usaha tersebut konstan terjadi pada tahun 2011 hingga 2012. Selanjutnya pada tahun 2013 hingga 2015 terdapat rencana realisasi namun capaian dari realisasi tersebut tidak ada, sehingga persentase realisasinya adalah sebesar 0\% (Gambar 3.a).

Sementara itu sektor usaha yang berkontribusi pada realisasi PMDN Kabupaten Fakfak adalah sektor usaha kehutanan yang bergerak di bidang usaha logging dan sektor usaha industri lainnya di bidang usaha industri veneer, masing-masing sebesar 51,58\% dan 214\%. Kemudian pada tahun 2012 sektor usaha kehutanan meningkat menjadi 70,89\% dan sektor usaha industri lainnya menurun drastis menjadi $0 \%$. Sektor usaha industri di bidang usaha industri kayu yang semula di tahun 2011 mempunyai realisasi 0\%, di tahun 2012 mempunyai realisasi sebesar 85,04\% (Gambar 3.b). Selanjutnya pada tiga tahun terakhir, ketiga sektor usaha tersebut tidak lagi memiliki realisasi investasi. Hal ini diduga karena semakin baiknya pengawasan pada kehutanan terutama pelarangan logging. Sementara 
itu untuk industri kayu belum juga terjadi realisasi investasi diduga karena besaran kayu yang hendak diolah belum memenuhi syarat, sehingga industri tidak ingin mengambil resiko kegagalan. Kondisi ini menjadi penting untuk diperhatikan daerah Kabupaten Fakfak, sebagai daerah potensial kayu maupun hasil hutan lainnya. Larangan pengusahaan kayu bukan berarti harus menghentikan investasi di bidang perkayuan dan kehutanan, namun seharusnya diarahkan kepada industri perkayuan maupun hasil hutan lainnya.

Pada gambar 3.c terlihat bahwa sektor usaha pada investasi di Kota Sorong adalah sektor usaha kehutanan d bidang logging dan sektor usaha industri kayu dibidang industri kayu dan plywood blockboard. Capaian realisasi ini hanya terjadi pada Tahun 2011 dan 2012, tahun 2013 hingga 2015 tidak terdapat realisasi. Hal ini diduga karena semakin baiknya pengawasan pada kehutanan terutama pelarangan logging. Sementara itu untuk industri kayu belum juga terjadi realisasi investasi diduga karena besaran kayu yang hendak diolah belum memenuhi syarat, sehingga industri tidak ingin mengambil resiko kegagalan.

Sementara itu dari gambar 3.d terlihat, Realisasi PMDN di Kabupaten Teluk Bintuni pada tahun

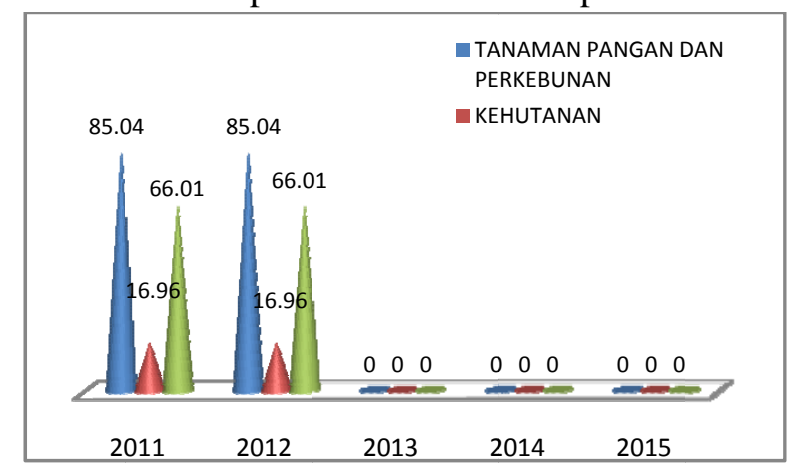

a) Kabupaten Kaimana

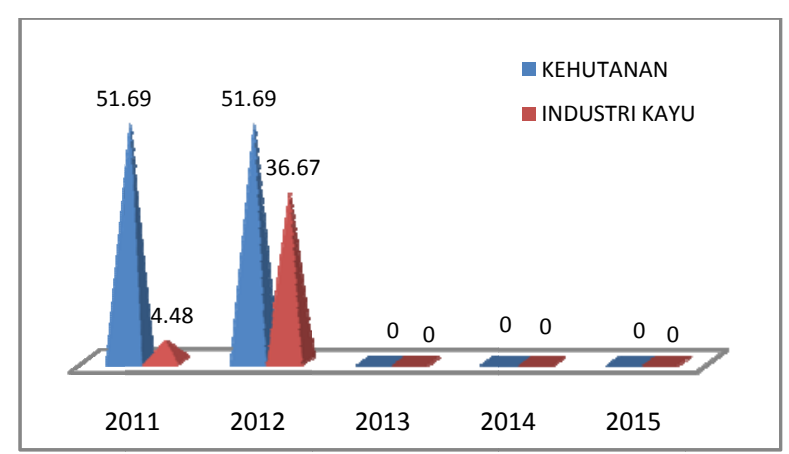

c) Kota Sorong
2011 berasal dari sektor usaha kehutanan dibidang usaha logging sebesar 661,36\%, kemudian pada tahun 2011 realisasi ini berubah sektor usaha menjadi sektor usaha industri lainnya yang bergerak di bidang usaha indutri chips dengan jumlah realisasi yang sama. Perubahan ini terjadi karena pada tahun 2012 sudah terdapat kebijkan yang melarang logging, sehingga perusahaan berpindah usaha di bidang industri pengolahan kayu. Selanjutnya pada 3 (tiga) tahun terakhir tidak terjadi realisasi investasi disebabkan karena semakin baiknya penerapan kebijakan mengenai pelarangan logging tersebut.

Capaian realisasi PMDN di Kabupaten Raja Ampat berasal dari sektor usaha jasa lainnya yang bergerak dibidang jasa pariwisata yaitu sebesar 131,2\% pada tahun 2011 dan 2012. Tingginya capian realisasi investasi di bidang pariwisata disebabkan oleh kondisi keindahan bawah laut yang dapat menarik para wisatawan. Namun tahun 2015 tidak ada capaian realisasi sektor ini meskipun terdapat rencana investasinya. Terdapat juga sektor usaha kehutanan yang bergerak di bidang Sawmill, Moulding dan Drykin yang meskipun terdapat rencana investasi, namun capaian realisasi sektor kehutanan tidak ada (Gambar 3.e).

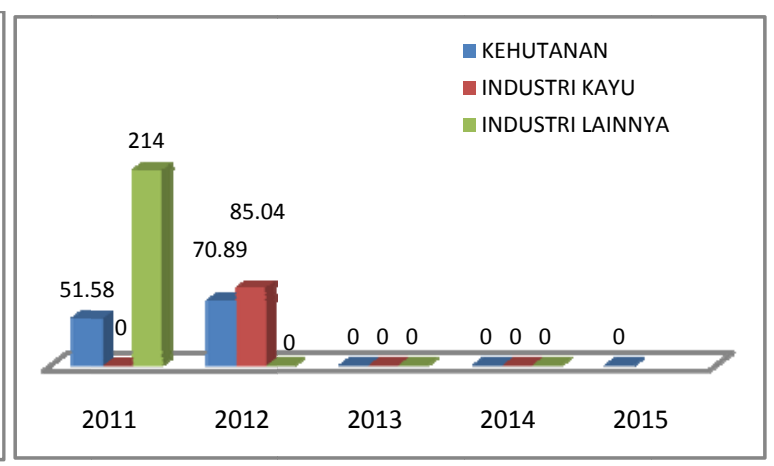

b) Kabupaten Fakfak

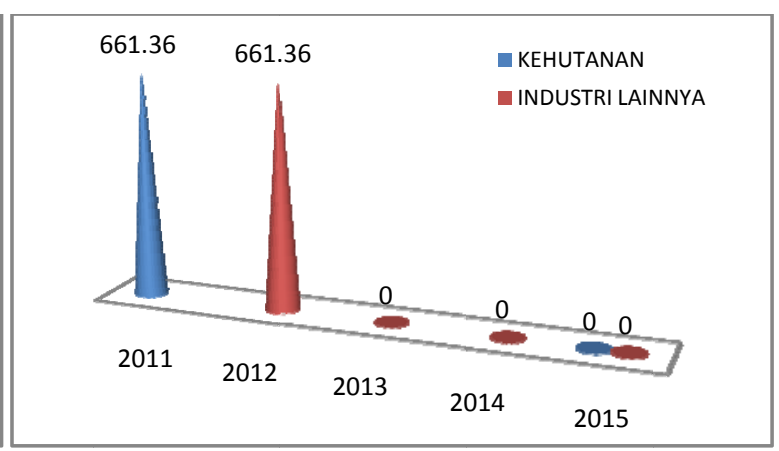

d) Kabupaten Teluk Bintuni

Journal of Fiscal and Regional Economy Studies 


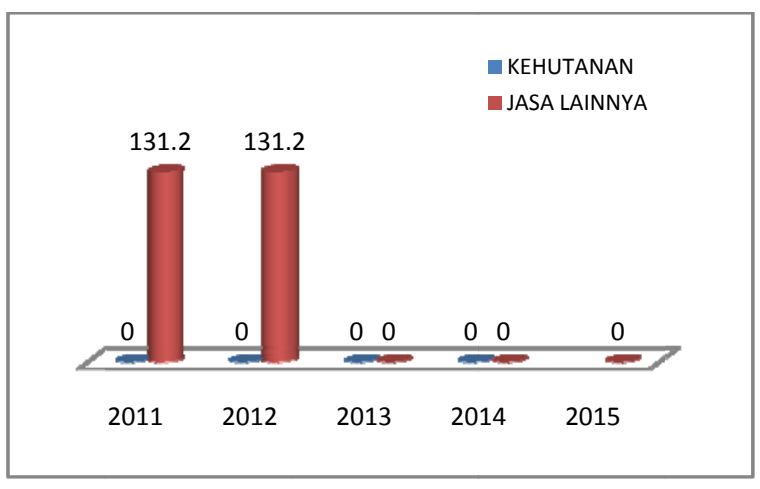

e) Kabupaten Raja Ampat

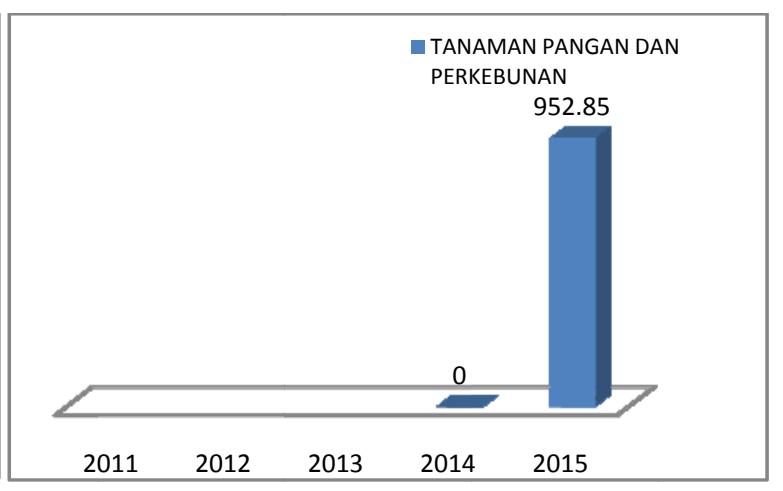

f) Kabupaten Maybrat

Gambar 3. Realisasi PMDN Kabupaten Kota Tahun 2011-2015 (\%)

Kabupaten Maybrat adalah daerah pemekaran yang administrasi daerahnya baru dimulai sejak Tahun 2010. Capaian realisasi Kabupaten Maybrat berasal dari sektor usaha tanaman pangan dan perkebunan di bidang usaha perkebunan kelapa sawit. Rencana investasi telah ada sejak tahun 2014, namun baru terealisasi pada tahun 2015 sebesar 952,85\%. Nilai realisasi tersebut sudah cukup baik bagi kabupaten yang baru di bentuk pada tahun 2014 ini, seperti dapat dilihat pada Gambar 3.f.

\section{Serapan Tenaga Kerja Pada PMDN Papua Barat}

Serapan tenaga kerja adalah jumlah tenaga kerja yang dapat bekerja pada suatu unit usaha. Serapan tenaga kerja yang akan di analisis adalah capaian realisasi tenaga kerja yang terserap pada PMDN di tiap kabupaten/kota, baik Tenaga Kerja Indonesia (TKI) maupun Tenaga Kerja Asing (TKA). Selain itu juga kan dilihat pertumbuhan capaian realisasi selama kurun waktu 5 (lima) tahun yaitu sejak tahun 2011-2015.

Berdasarkan Tabel 5, capaian realisasi penyerapan Tenaga Kerja Indonesia (TKI) pada PMDN Provinsi Papua Barat hanya terjadi pada 8 kabupaten. Kabupaten Manokwari memiliki capaian realisasi penyerapan TKI pada tahun 2011-2015 mengalami fluktuatif, namun cenderung mengalami penurunan, tahun 2011 capaian realisasi TKI sebanyak 165,31\% dan pada tahun 2015 sebanyak 16,43\%.

Pada kabupaten Kaimana, kota sorong, kabupaten Teluk Bintuni, dan kabupaten Raja Ampat, capaian realisasi TKI pada PMDN hanya terjadi pada tahun 2011 dan 2012 saja. Pada tahun 2013 hingga 2015 hanya terdapat rencana investasi namun tidak terjadi realisasi, sehingga capaian realisasi TKI adalah sebesar $0 \%$.

Capaian realisasi TKI pada kabupaten Fak-fak relatif stagnan pada tahun 2011-2012 yaitu

Tabel 5. Serapan TKI pada PMDN Tahun 2011-2015 (\%)

\begin{tabular}{rlrrrrr}
\hline \multirow{2}{*}{ No. Kabupaten/Kota } & \multicolumn{5}{c}{ Tahun } \\
\cline { 3 - 7 } & & $\mathbf{2 0 1 1}$ & $\mathbf{2 0 1 2}$ & $\mathbf{2 0 1 3}$ & $\mathbf{2 0 1 4}$ & $\mathbf{2 0 1 5}$ \\
\hline 1 & Manokwari & 165,31 & 169,81 & 2,80 & 2,73 & 16,43 \\
2 & Kaimana & 40,85 & 40,85 & 0 & 0 & 0 \\
3 & Fakfak & 65,33 & 65,33 & 0 & 20,07 & 66,67 \\
4 & Sorong & 6,63 & 7,65 & 0,24 & 0 & 7,56 \\
5 & Kota Sorong & 23,39 & 23,39 & 0 & 0 & 0 \\
6 & Bintuni & 39,50 & 354,50 & 0 & 0 & 0 \\
7 & Raja Ampat & 12,60 & 12,60 & 0 & 0 & 0 \\
8 & Maybrat & & & & 0 & 700 \\
\hline
\end{tabular}

Sumber: Data sekunder (diolah), 2016 
sebesar 65,33, kemudian menjadi $0 \%$ di tahun 2013, dan terus meningkat pada tahun 2014 dan 2015 dengan nilai capaian masing-masing adalah 20,07\% dan 66,67\%. Untuk kabupaten Maybrat, capaian realisasi TKI hanya terjadi pada tahun 2015 yaitu sebesar 700\%, nilai ini merupakan persentase terbesar dibanding dengan kabupaten lain.

Berdasarkan Tabel 6 terlihat bahwa capaian realisasi Tenaga Kerja Asing (TKA) pada PMDN di kabupaten Manokwari, kabupaten Kaimana, kabupaten Fakfak dan kota Sorong hanya terjadi pada tahun 2011 dan 2012. Sedangkan capaian realisasi TKA pada PMDN di kabupaten Sorong hanya terjadi pada tahun 2014 dan 2015 dengan nilai realisasi yang sama yaitu sebesar 5,56\%.

Apabila dilihat penyerapan tenaga kerja PMDN secara keseluruhan, maka tenaga kerja yang terserap pada PMDN lebih banyak berasal dari Tenaga Kerja Indonesia (TKI) dari pada Tenaga Kerja Asing (TKA). Hal ini sesuai dengan Pasal
10 UU PM menyebutkan bahwa: Perusahaan penanaman modal dalam memenuhi kebutuhan tenaga kerja harus mengutamakan tenaga kerja warga negara Indonesia dan perusahaan penanaman modal berhak menggunakan tenaga ahli warga negara asing untuk jabatan dan keahlian tertentu sesuai dengan ketentuan peraturan perundang-undangan.

\section{Perkembangan Investasi PMA di Provinsi Papua Barat}

Perkembangan investasi PMA di Provinsi Papua Barat dianalisis selama lima tahun terakhir yaitu tahun 2011-2015. Pada tahun 2011-2013 dilakukan analisis pada 10 kabupaten dan 1 kota sedangkan pada tahun 2014-2015 dilakukan analisis di 12 kabupaten dan 1 kota. Perkembangan investasi PMA dianalisis baik rencana maupun realisasi investasi yang terjadi di Provinsi Papua Barat. Perkembangan realisasi PMA tersebut dapat dilihat pada Gambar 4.

Tabel 6. Serapan TKA pada PMDN Tahun 2011-2015 (\%)

\begin{tabular}{rlrrrrrr}
\hline \multirow{2}{*}{ No. Kabupaten/Kota } & & \multicolumn{5}{c}{ Tahun } \\
\cline { 3 - 7 } & & $\mathbf{2 0 1 1}$ & $\mathbf{2 0 1 2}$ & $\mathbf{2 0 1 3}$ & $\mathbf{2 0 1 4}$ & \multicolumn{2}{c}{$\mathbf{2 0 1 5}$} \\
\hline 1 & Manokwari & 4,23 & 3,14 & 0 & 0 & 0 \\
2 & Kaimana & 50,00 & 63,64 & 0 & 0 & 0 \\
3 & Fakfak & 5,00 & 5,00 & 0 & 0 & 0 \\
4 & Sorong & 0 & 0 & 0 & 5,56 & 5,56 \\
5 & Kota Sorong & 8,33 & 8,33 & 0 & 0 & 0 \\
\hline
\end{tabular}

Sumber: Data sekunder (diolah), 2016

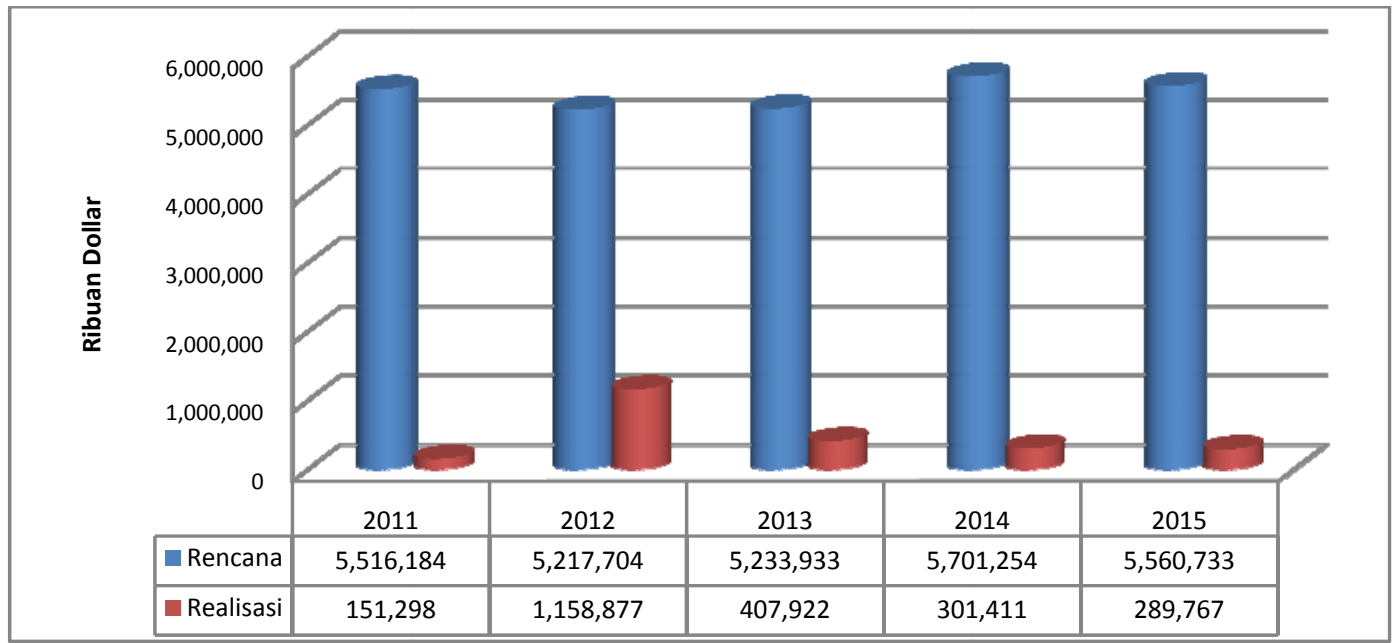

Gambar 4. Rencana dan realisasi PMA Provinsi Papua Barat 2011-2015 
Berdasarkan data Gambar 4, rencana investasi PMA di Papua Barat mengalami fluktuasi. Rencana investasi PMA pada tahun 2011 adalah sebesar US\$ 5.516.184.000 dengan realisasi hanya sebesar US\$.151.298.000. Tahun 2012 rencana realisasi menurun menjadi US\$ 5.217.704.000, namun realisasi investasinya meningkat menjadi US\$ 1.158.877.000, nilai ini melampaui target Nasional yang diberika BKPM kepada Provinsi Papua Barat di tahun 2013.

Di tahun 2013 rencana investasi meningkat menjadi US\$.5.233.933.000, peningkatan ini dipengaruhi oleh beralihnya status sejumlah PMDN menjadi PMA. Namun realisasi investasi 2013 menurun drastis menjadi US\$. 407.411.000 atau sebesar Rp. 3.916.051.200.000. Walaupun mengalami penurunan, namun nilai realisasi investasi ini melebihi target nasional yaitu sebesar Rp. 2.141.849.976.000.

Pada tahun 2014, rencana realisasi PMA meningkat dibanding 2013 yaitu menjadi US\$. 5.071.254.000. Hal ini dipengaruhi oleh masuknya sejumlah PMA yang berinvestasi di Papua Barat. Peningkatan rencana PMA, tidak berarti terjadi peningkatan pula pada realisasi investasinya, karena realisasi invetasi tahun 2014 menurun menjadi US\$. 301.411 .000 atau sebesar Rp. 3.164.815.500.000. Jumlah ini mencapai 98\% dari target nasional yang diberikan BKPM RI yaitu sebesar Rp. 3.700.000.000.000.

Tahun 2015, rencana PMA mengalami penurunan menjadi sebesar US\$. 5.560.733.000, hal sama juga terjadi pada realisasi PMA yaitu menjadi sebesar US\$. 289.767.000 atau sebesar Rp. 3.622.087.500.000. Penurunan ini terjadi karena BPMP2T mulai mengelompokkan PMA yang tidak taat menyampaikan Laporan Kegiatan Penanaman Modal (LKPM) kepada pemerintah pusat. Dan sebanyak 25 (dua puluh lima) PMA yang beroprasi di wilayah Papua Barat tidak menaati ketentuan peraturan pemerintah sehingga PMA tersebut dikenai sanksi pencabutan/ pembatalan Ijin Prinsip Penanaman Modal oleh BKPM RI sesuai kewenangannya.

\section{Perkembangan PMA berdasarkan Kabupaten/ Kota}

Perkembangan PMA berdasarkan kabupaten ini akan dilakukan di seluruh kabupaten dan kota yang ada di Papua Barat. Perkembangan ini dilakukan dengan menganalisis perkembangan realisasi PMA pada setiap kabupaten/kota sejak tahun 2011 hingga tahun 2015. Uraian mengenai perkembangan PMA berdasarkan kabupaten/ kota dapat dilihat pada Tabel 7. Capaian realisasi PMA Kabupaten Manokwari sejak tahun 2011 hingga 2015 mengalami fluktuasi, namun cenderung meningkat. Dari tahun 2011 capaian realisasi sebesar $4,93 \%$ dan meningkat cukup tinggi menjadi $77,52 \%$ di tahun 2015. Peningkatan ini disebabkan karena adanya peningkatan capaian realisasi PMA sektor usaha industri lainnya di bidang usaha industri semen yang berasal dari negara RRC. Berbeda dengan Kabupaten Manokwari, dua belas kabupaten lain juga mengalami perkembangan investasi yang fluktuatif namun cenderung mengalami menurun di tahun 2015. Rendahnya keinginan perusahaan PMA untuk berinvestasi disebabkan oleh beberapa faktor diantaranya: (1) Rendanya Keamanan, (2) Keterbatasan infrastruktur, (3) Belum adanya peta potensi sektor unggulan. Rendahnya keamanan ini terjadi ketika perusahaan yang telah beroperasi kemudian dihadapkan dengan masalah klaim peta kepemilikan hak ulayat berdasarkan marga yang akan memicu terjadinya konflik yang akan merugikan pihak perusahaan. Keterbatasan infrastruktur seperti jalan, pelabuhan laut, pelabuhan udara, listrik, dan jaringan telekomunikasi antar kabupaten/ kota dapat menyebabkan tingginya biaya produksi, biaya koleksi dan biaya distribusi. Belum adanya peta potensi sektor unggulan, dimana peta potensi sektor unggulan sangat bermanfaat bagi para investor asing guna mendapatkan informasi mengenai daerah dan sektor yang akan ditetapkan untuk dilakukan penanaman modal. 
Tabel 7. Realisasi PMA Berdasarkan Kabupaten/Kota Tahun 2011-2015 (\%)

\begin{tabular}{clrrrrr}
\hline \multirow{2}{*}{ No. Kabupaten/Kota } & \multicolumn{7}{c}{ Tahun } \\
\cline { 3 - 7 } & & $\mathbf{2 0 1 1}$ & $\mathbf{2 0 1 2}$ & $\mathbf{2 0 1 3}$ & $\mathbf{2 0 1 4}$ & $\mathbf{2 0 1 5}$ \\
\hline 1 & Manokwari & 4,93 & 4,66 & 18,57 & 0,57 & 77,52 \\
2 & Kaimana & 0 & 0 & 0 & 0 & 0,40 \\
3 & Fakfak & 0 & 0 & 187,65 & 0 & 0 \\
4 & Sorong & 1,27 & 3,62 & 4,72 & 0,48 & 0,20 \\
5 & Kota Sorong & 24,38 & 33,64 & 7,34 & 0 & 2,61 \\
6 & Teluk Bintuni & 2,10 & 171,41 & 0,13 & 20,62 & 0,44 \\
7 & Teluk Wondama & 0 & 0 & 0 & 0 & 0 \\
8 & Raja Ampat & 29,02 & 21,58 & 117,70 & 58,34 & 11,78 \\
9 & Sorong Selatan & 0 & 19,61 & 1,92 & 3,99 & 6,35 \\
10 & Maybrat & 0 & 1,76 & 10,39 & 4,16 & 0 \\
11 & Tambrauw & & & & 0 & 0 \\
11 & Manokwari Selatan & & & & 81,76 & 0 \\
12 & Pegunungan Arfak & & & & 0,34 & 0,003 \\
\hline
\end{tabular}

Sumber: Data sekunder (diolah), 2016

\section{Perkembangan PMA Berdasarkan Sektor Usaha}

Perkembangan PMA berdasarkan sektor usaha akan dilakukan pada setiap sektor usaha pada setiap kabupaten/ kota yang ada di provinsi Papua Barat. Sektor usaha usaha tersebut diantaranya adalah sektor tanaman pangan dan perkebunan, sektor perikanan, sektor kehutanan, sektor pertambangan, sektor industri kayu, sektor industri kimia, sektor industri lainnya, sektor perdagangan dan reparasi, sektor hotel dan restoran dan sektor jasa lainnya.

Berdasarkan data pada Tabel 8, sektor usaha yang berkontribusi dalam PMA kabupaten Manokwari adalah sektor usaha tanaman pangan dan perkebunan yang bergerak dibidang usaha perkebunan coklat, perkebunan kelapa dan tanaman fanili, nama negara yang berinvestasi tidak diketahui. Capaian realisasi sektor tanaman pangan dan perkebunan mengalami fluktuasi dari tahun 2011 sebesar 76,67\%, menurun menjadi 39,01\% di tahun 2012 dan meningkat cukup tinggi di tahun 2013 menjadi 281,62\%. Selanjutnya di tahun 2014 dan 2015 tidak terdapat capaian realisasi.

Capaian realisasi PMA pada sektor usaha perikanan di bidang usaha industri pengalengan ikan berasal dari RRC. Sektor usaha perikanan juga mengalami fluktuasi. Tahun 2011 capaian realisasi adalah sebesar 23,61,menurun menjadi 20,45\% di tahun 2012 dan meningkat di tahun 2013 menjadi 53,53\%.

Capaian realisasi PMA sektor usaha industri lainnya di bidang usaha industri komponen bangunan dan industri semen berasal dari RRC. Realisasi ini terus mengalami peningkatan dan hanya terjadi pada tahun 2013 hingga 2015. Pada tahun 2013 hanya sebesar 0,01, tahun 2014 sebesar 0,06 dan tahun 2015 meningkat drastis menjadi sebesar 79,89\%. Hal ini karena perusahaan tersebut berinvestasi cukup besar dengan mendirikan pabrik semen. Sektor usaha perdagangan dan reparasi di bidang perdagangan besar yang berasal dari negara RRC, tidak memiliki capaian realialisasi dikarenakan perusahaan yang besangkutan tidak melaporkan kegiatan PMA yang dilakukan.

Sektor usaha yang berkontribusi dalam PMA kabupaten Sorong adalah sektor usaha tanaman pangan dan perkebunan yang bergerak dibidang usaha perkebunan kelapa sawit, asal negara yang berinvestasi tidak diketahui.

Capaian realisasi sektor tanaman pangan dan perkebunan mengalami fluktuasi dari tahun 2011 sebesar 1,53\%, meningkat ditahun 2012 dan 2013 menjadi 4,41\% dan 5,16\%, namun di tahun 2014 dan 2015 mengalami penurunan menjadi $0,01 \%$ dan $0,03 \%$. 
Tabel 8. Realisasi PMA Kabupaten/Kota Tahun 2011-2015 (\%)

\begin{tabular}{|c|c|c|c|c|c|}
\hline \multirow{2}{*}{ Sektor Usaha } & \multicolumn{5}{|c|}{ Tahun } \\
\hline & 2011 & 2012 & 2013 & 2014 & 2015 \\
\hline \multicolumn{6}{|l|}{ A. Kabupaten Manokwari } \\
\hline Tanaman pangan dan perkebunan & 76,67 & 39,01 & 281,62 & 0 & 0 \\
\hline Perikanan & 23,61 & 20,45 & 53,53 & 0 & 0 \\
\hline Industri lainnya & 0 & 0 & 0,01 & 0,60 & 79,89 \\
\hline Perdagangan dan reparasi & 0 & 0 & 0 & 0 & \\
\hline Jasa lainnya & 0 & 0 & 8,58 & 0 & 0 \\
\hline \multicolumn{6}{|l|}{ B. Kabupaten Sorong } \\
\hline Tanaman pangan dan perkebunan & 1,53 & 4,41 & 5,16 & 0,10 & 0,03 \\
\hline Perikanan & 0 & 0 & 0 & 0 & 0 \\
\hline Industri kayu & 0,37 & 0,37 & 0 & 0 & 0 \\
\hline Industri kimia & 0 & 0 & 0 & 0 & \\
\hline Industri lainnya & 0 & 0 & 1,02 & 3,95 & 0,04 \\
\hline Perdagangan & 0 & 0 & 0 & 0 & 0 \\
\hline \multicolumn{6}{|l|}{ C. Kota Sorong } \\
\hline Perikanan & 112,77 & 50,68 & 19,50 & 0 & 1,62 \\
\hline Industri lainnya & 299,74 & 0 & 0,57 & 0 & 61,10 \\
\hline Perdagangan & 0 & 0 & 0,01 & 0,60 & 5,14 \\
\hline Hotel dan restoran & & 14,74 & 0 & 0 & 1,36 \\
\hline Jasa lainnya & 0 & 0 & 0,56 & 0 & 0 \\
\hline \multicolumn{6}{|l|}{ D. Kabupaten Teluk Bintuni } \\
\hline Pertambangan & 0 & 1,02 & 0 & 0 & 0 \\
\hline Industri kayu & 101,50 & 101,50 & 0 & 0 & 0 \\
\hline Jasa lainnya & 0 & 43.437,95 & 33,91 & 591,31 & 10,80 \\
\hline \multicolumn{6}{|l|}{ E. Kabupaten Raja Ampat } \\
\hline Perikanan & 69,45 & 108,30 & 0 & 84,64 & 0,89 \\
\hline Pertambangan & 14,04 & 1,95 & 221,43 & 218,15 & 79,58 \\
\hline Hotel dan restoran & 322,37 & 19,79 & 20,27 & 33,17 & 3,19 \\
\hline Jasa lainnya & 0 & 0 & 0 & 0 & 0 \\
\hline \multicolumn{6}{|l|}{ F. Kabupaten Sorong Selatan } \\
\hline Tanaman pangan dan perkebunan & 0 & 0,43 & 2,01 & 4,39 & 4,95 \\
\hline Kehutanan & 0 & 345,72 & 0,56 & 0 & 24,61 \\
\hline Jasa lainnya & 0 & 0 & 0 & 0 & 0 \\
\hline
\end{tabular}

Sumber: Data sekunder (diolah), 2016

Untuk sektor usaha perikanan dibidang penangkapan ikan serta industri pembekuan yang berasal dari negara Philipina, hanya terdapat perencaan realisasi, sedangkan capaian realisasi tidak ada. Hal ini di duga karena perusahaan PMA tidak melaporkan kegiatan penanaman modal yang dilakukan. Hal yang sama juga terjadi pada sektor usaha industri kimia di bidang industri kimia dasar organik dan sektor usaha perdagangan di bidang usaha perdagangan ekspor.

Untuk bidang usaha industri kayu di bidang usaha industri bahan bangunan dari kayu, hanya memiliki capaian realisasi PMA pada tahu 2011 dan 2012 yaitu sebesar 0,37\%. Hal ini sama terjadi pada sektor usaha hotel dan restoran yang bergerak di bidang usaha jasa akomodasi dan rekreasi juga hanya terdapat pada tahun 2011 dan 2012 yaitu sebesar 39,02\%.

Sektor usaha yang berkontribusi dalam PMA Kota Sorong adalah sektor usaha kehutanan di bidang usaha pengusahaan hutan dan industri perkayuan, realisasi yang terjadi pada tahun 2011 hingga 2014 adalah sebesar 0\%, artinya terjadi rencana realisasi pada sektor kehutanan. Namun perusahaan yang bersangkutan tidak 
memberikan Laporan Kegiatan Penanaman Modal (LKPM), sehingga tidak ada capaian realisasi. Pada sektor usaha perikanan di bidang usaha penangkapan ikan dan udang (berasal dari Jepang dan RRC), realisasi investasi cenderung menurun selama lima tahun terakhir. Hal ini disebabkan oleh adanya moratorium perijinan penangkapan ikan yang dikeluarkan oleh Kementerian Kelautan dan Perikanan RI. Pada sektor usaha industri lainnya di bidang usaha pengolahan air bersih dan industri kaleng (berasal dari Belanda dan Canada), terjadi fluktuasi dari 2011 hingga 2015. Pada sektor usaha perdagangan di bidang usaha perdagangan besar, realisasi PMA pada tahun 2015 yaitu sebesar 5,14\%. Berdasarkan data pada Tabel 8.d, sektor usaha yang berkontribusi dalam PMA Kabupaten Teluk Bintuni adalah sektor usaha pertambangan d ibidang usaha pertambangan batubara, hanya terjadi pada tahun 2012 yaitu sebesar $1,02 \%$. Sektor usaha industri kayu di bidang usaha industri veneer dan bahan bangunan, mengalami realisasi di tahun 2011 dan 2012 yaitu sebesar 101,50\%, kemudian tiga tahun terakhir tidak terjadi realisasi. Pada sektor usaha jasa lainnya di bidang usaha jasa penunjang pertambangan migas menalami penurunan realisasi sejak tahun 2012 yaitu sebesar 43.437,95\% menjadi hanya sebesar 10,80\% di tahun 2015. Hal ini diduga karena terdapat perusahaan PMA yang tidak lagi melaporkan kegiatan penanaman modalnya.

Sektor usaha yang berkontribusi dalam PMA Kabupaten Raja Ampat adalah sektor usaha perikanan di bidang usaha budidaya mutiara berasal dari Jepang memiliki realisasi yang fluktuatif sejak 5 (lima) tahun terakhir. Pada tahun 2011, realisasi sektor perikanan adalah sebesar $69,45 \%$ dan menjadi $0,89 \%$ di tahun 2015. Kontribusi selanjutnya diberikan oleh sektor usaha pertambangan yang bergerak di bidang usaha pertambangan umum brasal dari Australia dengan nilai realisasi yang fluktuatif.

Pada tahun 2011 nilai realisasi investasi bidang usaha pertambangan adalah sebesar $14,04 \%$ dan terus meningkat menjadi $221,43 \%$ di tahun
2013, kemudian mengalami penurunan ditahun 2015 menjadi sebesar 79,58\%.

Sektor usaha Hotel dan restoran yang bergerak di bidang pariwisata dan jasa akomodasi di bidang usaha pariwisata dan jasa akomodasi yang berasal dari negara Belanda dan Swiss memiliki realisasi investasi yang relatif menurun dari tahun 2011-2015. Tahun 2011 realisasi sektor usaha ini adalah sebesar 322,37 dan menurun drastis ditahun 2015 menjadi sebesar 3,39\%.

Realisasi PMA Kabupaten Sorong Selatan adalah dari sektor usaha tanaman pangan dan perkebunan di bidang usaha perkebunan kelapa sawit, yang mengalami peningkatan dari tahun 2011 adalah sebanyak 0\% menjadi 4,95\% di tahun 2015. Kemudian sektor usaha kehutanan di bidang usaha pengusahaan kayu, dengan kontribusi yang cukup besar di tahun 2012 yaitu sebesar 345,72\% dan menurun hingga menjadi 24,61\% di tahun 2015.

Capaian realisasi PMA pada Kabupaten Kaimana hanya terjadi pada tahun 2015 yaitu sebesar $25 \%$ pada sektor usaha hotel dan restoran pada bidang usaha hotel melati dan wisata selam yang berasal dari kerjasama negara Kanada, Inggris dan Indonesia (Gambar 5a).

Capaian realisasi PMA pada kabupaten Fakfak hanya terjadi pada tahun 2013 yaitu sebesar 925,93\% pada sektor usaha pertambangan di bidang usaha penyediaan tenaga listrik yang berasal dari negara Singapura. Sektor usaha perikanan, sektor hotel dan restoran, serta sektor usaha jasa lainnya tidak memiliki capaian realisasi namun terdapat perencanaan dalam PMA (Gambar 5b).

Berdasarkan Gambar 5c), sektor usaha yang memberikan kontribusi pada realisasi PMA Kabupaten Maybrat adalah sektor usaha tanaman pangan dan perkebunan di bidang usaha perkebunan kelapa sawit dari negara Singapura dan sektor usaha pertambangan dibidang usaha pertambangan. Capaian realisasi sektor tanaman pangan dan perkebunan terjadi pada 2013 hingga 2015 dan mengalami fluktuasi. Sedangkan capaian realisasi sektor pertambangan hanya terjadi pada tahun 2013 yaitu sebesar 0,83\%. 


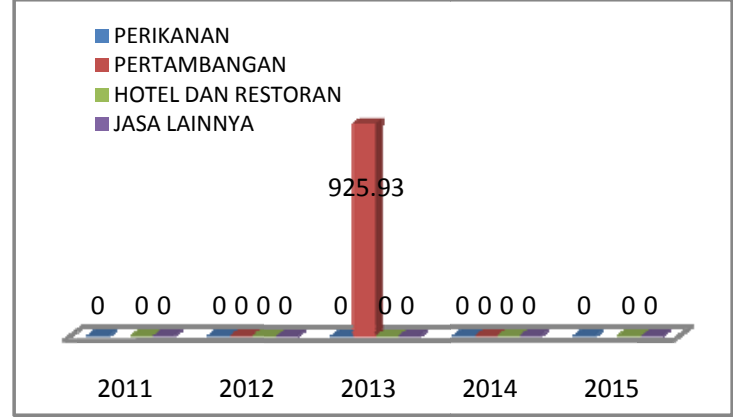

a) Kabupaten Kaimana

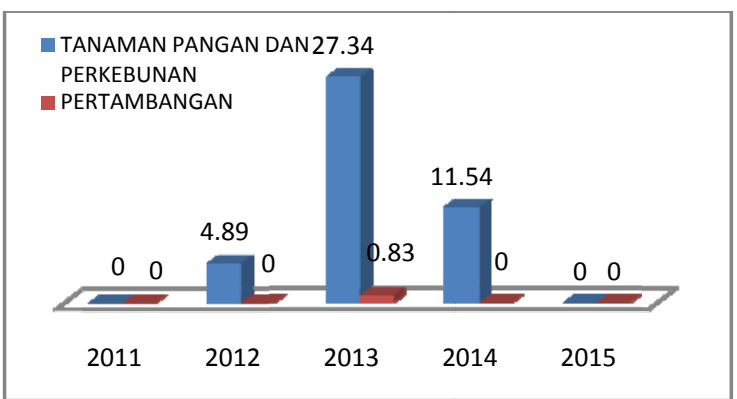

c) Kabupaten Maybrat

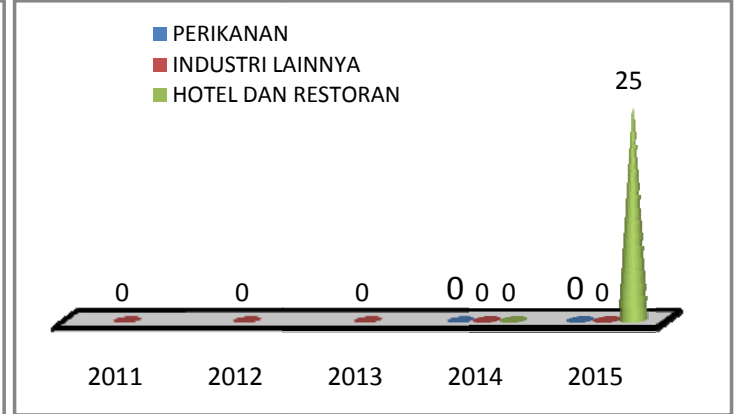

b) Kabupaten Fakfak

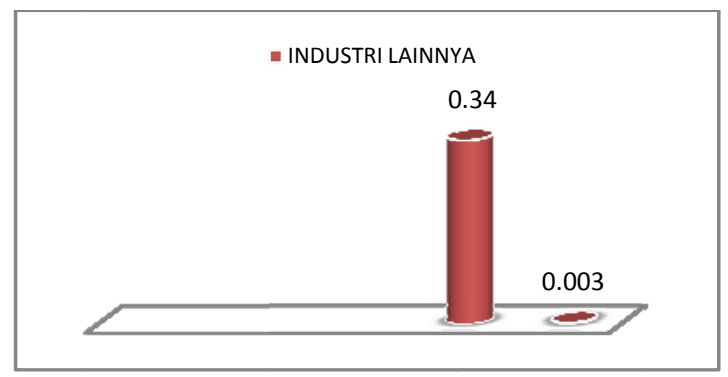

e) Kabupaten Maybrat

Gambar 5. Realisasi PMA Kabupaten/Kota Tahun 2011-2015 (\%)

Berdasarkan Gambar 5d), capaian realiasi Kabupaten Manokwari Selatan pada tahun 2014 adalah sebesar $81,76 \%$ dan menurun drastis menjadi $0 \%$ di tahun 2015. Nilai tersebut disumbangkan oleh sektor usaha industri lainnya di bidang perdagangan besar yang berasal dari RRC dan Hongkong. Untuk kabupaten baru yang telah ditetapakan sejak tahun 2014, kabupaten Manokwari Selatan sudah memiliki capaian realisasi PMA yang cukup tinggi.

Berdasarkan Gambar 5e), capaian realisasi PMA Kabupaten Pegunungan Arfak merupakan kontribusi dari sektor usaha industri lainnya di bidang pembangkit tenaga listrik, air dan gas yang berasal dari RRC. Capaian tersebut terjadi pada tahun 2014 yaitu sebesar 0,34\% dan menurun di tahun 2015 menjadi 0,003\%.

\section{Serapan Tenaga Kerja Pada PMA Papua Barat}

Serapan tenaga kerja yang akan dianalisis adalah capaian realisasi tenaga kerja yang terserap pada PMA di tiap kabupaten/kota, baik tenaga kerja Indonesia (TKI) maupun tenaga kerja asing (TKA). Selain itu juga akan dilihat pertumbuhan capaian realisasi selama kurun waktu 5 tahun yaitu sejak tahun 2011-2015 (Tabel 9).

Capaian penyerapan TKI pada PMA Provinsi Papua Barat hanya terjadi pada 7 kabupaten. realisasi penyerapan TKI di Kabupaten Manokwari pada tahun 2011-2014 mengalami fluktuatif, namun cenderung mengalami penurunan. Tahun 2011 capaian realisasi TKI sebanyak 15,95\%, meningkat sebesar 28,08\% di tahun 2012, kemudian mengalami penurunan di tahun 2013 dan 2014 menjadi 3,10\% dan 0,56\%. Realisasi penyerapan TKI di Kabupaten 
Tabel 9. Serapan TKI Pada PMA Tahun 2011-2015 (\%)

\begin{tabular}{|c|c|c|c|c|c|c|}
\hline \multirow{2}{*}{ No. } & \multirow{2}{*}{ Kabupaten/Kota } & \multicolumn{5}{|c|}{ Tahun } \\
\hline & & 2011 & 2012 & 2013 & 2014 & 2015 \\
\hline 1 & Manokwari & 15,95 & 28,08 & 3,10 & 0,56 & \\
\hline 2 & Kaimana & 0 & 0 & 0 & 0 & 1,24 \\
\hline 3 & Fakfak & 0 & 0 & 437,39 & 0 & \\
\hline 4 & Sorong & 2,93 & 9,41 & 17,17 & 85,54 & 119,95 \\
\hline 5 & Kota Sorong & 25,02 & 13,87 & 9,29 & 15,73 & 21,55 \\
\hline 6 & Teluk Bintuni & 26,61 & 15,40 & 0,10 & 4,08 & 3,29 \\
\hline 7 & Raja Ampat & 9,06 & 14,96 & 4,06 & 44,21 & 76,74 \\
\hline
\end{tabular}

Sumber: Data sekunder (diolah), 2016

Kaimana, hanya terjadi pada tahun 2015 yaitu sebesar 1,24\%. Sedangkan untuk Kabupaten Fakfak, capaian realisasi penyerapan TKI hanya terjadi pada tahun 2013 yaitu sebesar 437,39\%. Kabupaten sorong memiliki capaian realisasi penyerapan TKI yang cenderung meningkat sejak tahun 2011 yaitu sebesar 2,93\% hingga menjadi 1119,95\% di tahun 2015. Realisasi serapan TKI di Kota Sorong pada tahun 2011 adalah sebesar $25,02 \%$, dan mengalami penurunan di tahun 2012 dan 2013 menjadi 13,87\% dan 9,29\%. Namun di tahun 2014 dan 2015 terjadi kenaikan yaitu sebesar $15,73 \%$ dan 21,55\%. Capaian realisasi TKI Kabupaten Teluk Bintuni cenderung menurun. Tahun 2011 capaian realisasi adalah sebesar 26,61\%, dan menjadi 3,29\% di tahun 2015. Sedangkan realisasi serapan TKI Kabupaten Raja Ampat cenderung meningkat, di tahun 2011 adalah sebesar 9,06 dan terus meningkat menjadi 76,75 di tahun 2015.

Tabel 10 menyajikan data serapan TKA pada PMA Papua Barat 2011-2015. Capaian realisasi tenaga kerja asing (TKA) pada PMA di kabupaten Manokwari cenderung mengalami penurunan dari tahun 2011 sebesar 235\% menjadi 65,63\% di tahun 2014, sedangkan pada tahun 2015 tidak terdapat realisasi TKA di Kabupaten Manokwari. Capaian realisasi TKA pada PMA di Kabupaten Sorong cenderung mengalami peningkatan dari tahun 2011 sebesar 12,12\% menjadi 194,29\% di tahun 2015. Berbeda dengan Kabupaten Sorong, capaian realisasi penyerapan TKA di kota Sorong cenderung mengalami penurunan dari tahun 2011 sebesar 14,78\% menjadi 3,08\% di tahun 2015. Untuk kabupaten Teluk Bintuni, capaian realisasi TKA hanya terdapat pada tahun 2012 dan 2013 yaitu sebesar 33,33\%.

Realisasi TKA pada PMA di Kabupaten Raja Ampat menalami fluktuasi dari tahun 20112015. Di tahun 2011, capaian realisasi pada tahun 2011 adalah sebesar 17,11\%, dan mengalami peningkatan yang cukup besar di tahun 2012 menjadi 196,95\%. Kemudian mengalami penurunan lagi di tahun 2013 dan 2014 menjadi 32,82\% dan 13, 74\%. Selanjutnya di tahun 2015 meningkat menjadi 20,14\%.

Tabel 10. Serapan TKA pada PMA tahun 2011-2015 (\%)

\begin{tabular}{llrrrrr}
\hline \multirow{2}{*}{ No. Kabupaten/Kota } & \multicolumn{7}{c}{ Tahun } \\
\cline { 3 - 7 } & & $\mathbf{2 0 1 1}$ & $\mathbf{2 0 1 2}$ & $\mathbf{2 0 1 3}$ & $\mathbf{2 0 1 4}$ & \multicolumn{2}{c}{$\mathbf{2 0 1 5}$} \\
\hline 1 & Manokwari & 235 & 223,81 & 5,00 & 65,63 & \\
2 & Sorong & 12,12 & 19,15 & 129,79 & 193,62 & 194,29 \\
3 & Kota Sorong & 14,78 & 7,54 & 3,09 & 1,93 & 3,08 \\
4 & Teluk Bintuni & 0 & 33,33 & 33,33 & 0 & 0 \\
5 & Raja Ampat & 17,11 & 196,95 & 32,82 & 44,21 & 76,74 \\
\hline
\end{tabular}

Sumber: Data sekunder (diolah), 2016 
Bila dilihat penyerapan tenaga kerja PMA secara keseluruhan, maka jumlah TKI yang terserap lebih banyak dari pada jumlah TKA. Hal ini sesuai dengan Pasal 10 UU PM menyebutkan bahwa perusahaan penanaman modal dalam memenuhi kebutuhan tenaga kerja harus mengutamakan tenaga kerja warga negara Indonesia. Sama halnya sesuai dengan Undang-Undang No.1 Tahun 1967 juga menyebutkan perusahaan asing mempunyai kewajiban untuk menggunakan tenaga kerja warga negara Indonesia dan menyelenggarakan dan atau memberikan fasilitas-fasilitas latihan dan pendidikan.

Bila dilihat dari sisi ketenagakerjaan, diduga upah minimum Provinsi Papua Barat masih jauh dibawah dari kehidupan layak tenaga kerja yaitu sekitar $87 \%$. Dengan tingkat upah yang demikian pun sudah jauh dari upah minimum pada umumnya kecuali jawa timur dan DKI Jakarta, hal ini menjadi pertimbangan bagi investor untuk merealisasikan investasinya, yang akan menyebabkan realisasi serapan tenaga kerja juga belum menjanjikan sehingga belum relatif tinggi.

\section{Penentuan Sektor Potensial dalam Perkem- bangan Investasi}

Penentuan sektor potensial dalam perkembangan investasi di papua Barat dapat dilakukan dengan melihat investasi baik PMDN maupun PMA di suatu kabupaten/ kota yang memiliki perkembangan investasi tertinggi. Selanjutanya dari perkembangan di kabupaten tersebut, akan terlihat sektor apa yang memiliki potensi perkembangan tertinngi dan berapa capaian realisasi penyerapan tenaga kerja yang terjadi.

Bila dilihat pada realisasi PMDN, maka kabupaten yang memiliki perkembangan realisasi investasi yang tertinggi adalah kabupaten Sorong. Realisasi investasi tersebut terjadi pada sektor usaha tanaman pangan dan perkebunan di bidang usaha perkebunan kelapa sawit. Adapun total realisasi serapan tenaga kerja baik TKI maupun TKA di tahun 2015 adalah sebesar $13,12 \%$.

Walaupun realisasi investasinya besar, sektor ini memiliki serapan tenaga kerja yang relatif kecil. Bila di dilihat dari penyerapan tenaga, maka kabupaten Manokwari memiliki serapan tenaga kerja lebih baik dibandingkan kabupaten Sorong, yaitu sebesar $16,43 \%$. Hal tersebut terjadi pada sektor usaha yang sama yaitu sektor usaha tanaman pangan dan perkebunan di bidang usaha perkebunan kelapa sawit.

Bila dilihat pada realisasi PMA, maka kabupaten yang memiliki perkembangan realisasi investasi yang tertinggi adalah kabupaten Raja Ampat. Realisasi investasi tersebut terjadi pada sektor usaha pertambangan di bidang usaha pertambangan umum dan pertambangan nikel. Adapun total realisasi serapan tenaga kerja baik TKI maupun TKA di tahun 2015 adalah sebesar $96,88 \%$.

Walaupun realisasi investasinya besar, sektor ini memiliki serapan tenaga kerja yang relatif kecil. Bila di dilihat dari penyerapan tenaga, maka kabupaten Sorong memiliki serapan tenaga kerja lebih baik dibandingkan kabupaten Raja Ampat, yaitu sebesar 314,24\%. Hal tersebut terjadi pada sektor usaha jasa lainnya di bidang usaha jasa penunjang migas.

\section{KESIMPULAN}

Dari analisis tentang perkembangan investasi di Provinsi Papua Barat tahun 2011-2015, dapat disimpulkan beberapa hal sebagai berikut:

1. Perkembangan realisasi investasi PMDN di Papua barat mengalami peningkatan dari tahun 2011 hingga 2014 yang disebabkan semakin baiknya administrasi perijinan mengenai penanaman modal yang dikeluarkan oleh Badan Penanaman Modal dan Pelayanan Perijinan Terpadu (BPMP2T). Perkembangan realisasi investasi PMA di Papua Barat mengalami fluktuasi namun cenderung mengalami penurunan. Walaupun mengalami penurunan, namun nilai realisasi tahun 2012 hingga 2014 selalu melebihi target nasional yang diberikan oleh Badan Koordinasi Penanaman Modal (BKPM) RI.

2. Kabupaten yang memiliki nilai realisasi PMDN tertinggi adalah kabupaten Sorong. Sektor potensial adalah sektor usaha tanaman pangan dan perkebunan di bidang usaha perkebunan kelapa sawit. Adapun total realisasi serapan tenaga kerja baik TKI maupun 
TKA di tahun 2015 adalah sebesar 13,12\%. Kabupaten yang memiliki nilai realisasi PMA tertinggi adalah kabupaten Raja Ampat. Sektor potensial adalah sektor usaha pertambangan di bidang usaha pertambangan umum dan pertambangan nikel. Adapun total realisasi serapan tenaga kerja baik TKI maupun TKA di tahun 2015 adalah sebesar $96,88 \%$.

\section{DAFTAR PUSTAKA}

Arsyad, Lincolin. 1999. Pengantar Perencanaan dan Pembangunan Ekonomi Daerah, Edisi Pertama. Yogyakarta: BPFE.

Arsyad, Lincolin. 2004. Ekonomi Pembangunan Edisi ke Empat. Yogyakarta: Bagian Penerbitan Sekolah Tinggi Ilmu Ekonomi YKPN

Badan Pusat Statistik Provinsi Papua Barat. 2013. Papua Barat Dalam Angka Provinsi Papua Barat 2013

Badan Pusat Statistik Provinsi Papua Barat 2015. Papua Barat Dalam Angka Provinsi Papua Barat 2015
BPMP2T. 2016. Perkembangan Penanaman Modal di papua Barat Tahun 2011-2015. Papua Barat: BPMP2T.

BPPD Papua Barat. 2016. Rencana Pengembangan Wilayah dan Investasi Provinsi Papua Barat 2007-2026. (Online) diakses dari http://www.batukarinfo.com/system/ files/ Bab\%207\%20Final.pdf, pada tanggal 30 April 2016.

Suryana. 2000. Teori-teori Pertumbuhan Ekonomi, Ekonomi Pembangunan: Teori, Masalah dan Kebijakan. UPP AMP YKPN Yogyakarta.

Syaharani. 2011. Syaharani, Febrina. 2011. "Pengaruh Penanaman Modal Dalam Negeri, Penanaman Modal Asing, dan Utang Luar Negeri Terhadap Pertumbuhan Ekonomi Indonesia”. Skripsi, Universitas Negeri Syarif Hidayatullah, Jakarta.

Tarmidi, Lepi T. 1992. Ekonomi Pembangunan. Jakarta: Pusat Antar Universitas EK-UI.

Todaro, dkk. 2003. Pembangunan Ekonomi di Dunia Ketiga, edisi kedelapan. Jakarta. Erlangga. 